\title{
Effects of dry period length and dietary energy source on inflammatory biomarkers and oxidative stress in dairy cows
}

\author{
N. Mayasari, ${ }^{*}{ }^{1}$ J. Chen, ${ }^{*}$ A. Ferrari, $\ddagger$ R. M. Bruckmaier,§ B. Kemp, ${ }^{*}$ H. K. Parmentier, ${ }^{*}$ A. T. M. van Knegsel, ${ }^{* 1}$ \\ and E. Trevisił \\ *Adaptation Physiology Group, Department of Animal Science, Wageningen University, PO Box 338, 6700 AH Wageningen, the Netherlands \\ †Faculty of Animal Husbandry, Universitas Padjadjaran, 45636, Bandung, Indonesia \\ łlstituto di Zootecnica, Faculty of Agriculture, Food and Environmental Sciences, Università Cattolica del Sacro Cuore, 29122 Piacenza, Italy \\ $\S$ Veterinary Physiology, Vetsuisse Faculty, University of Bern, Bremgartenstrasse 109a, CH-25 3012 Bern, Switzerland
}

\begin{abstract}
Negative energy balance in dairy cows in early lactation has been associated with increased inflammation and oxidative stress in these cows. The objective of this study was to evaluate the effects of dry period (DP) length and dietary energy source on inflammatory biomarkers and oxidative stress in dairy cows. Holstein-Friesian dairy cows (60 primiparous and 107 multiparous) were assigned randomly to a $3 \times 2$ factorial design with $3 \mathrm{DP}$ length $(0,30$, or $60 \mathrm{~d})$ and 2 early lactation rations (glucogenic or lipogenic). Cows were fed a glucogenic or lipogenic ration from $10 \mathrm{~d}$ before the expected calving date. Blood was collected in wk $-3,-2,-1,1,2$, and 4 relative to calving. Dry period length affected inflammatory biomarkers and oxidative stress, especially in wk 1 and 2 after calving. Cows with a 0-d DP had higher levels of ceruloplasmin, cholesterol, and reactive oxygen metabolites, and they tended to have higher haptoglobin levels compared with cows with a $30-$ or $60-d$ DP. Cows with a $0-d$ DP had a lower plasma paraoxonase and bilirubin in the first 2 wk after calving and a lower liver functionality index compared with cows with a 60-d DP. Cows of parity $>3$ fed a glucogenic ration had higher cholesterol levels compared with cows of parity $>3$ fed a lipogenic ration. No interaction between DP length and ration was present for inflammatory biomarkers or oxidative stress variables. Plasma bilirubin levels for cows with a 0-d DP were negatively related to energy balance and metabolic status in these cows. Moreover, occurrence of clinical health problems (fever, mastitis, metritis, and retained placenta) was 41,27 , and $30 \%$ for cows with
\end{abstract}

\footnotetext{
Received August 10, 2016.

Accepted February 5, 2017.

${ }^{1}$ Corresponding authors: novi.mayasari@wur.nl or novim001@ gmail.com and ariette.vanknegsel@wur.nl
}

0-, 30-, and 60-d DP, respectively. High levels of ceruloplasmin, cholesterol, and reactive oxygen metabolites in cows with 0-d DP were related to the occurrence of health problems in these cows. In conclusion, omitting the DP increased levels of ceruloplasmin, cholesterol, and reactive oxygen metabolites, and decreased levels of bilirubin and paraoxonase in plasma, independent of ration, compared with cows with a $60-d$ DP. These contrasting effects of DP length on inflammatory status could be explained in part by the improved energy balance and occurrence of health problems in these cows, but was not related to increased somatic cell count in cows with a 0-d DP. Cows with a 0-d DP had better energy balance, but also had higher levels of oxidative stress compared with cows with a 60-d DP. Moreover, occurrence of health problems did not differ between cows with different DP lengths.

Key words: continuous milking, acute phase protein, oxidative stress, energy balance

\section{INTRODUCTION}

During the transition period, which lasts from $3 \mathrm{wk}$ before to $3 \mathrm{wk}$ after calving (Drackley, 1999), dairy cows experience negative energy balance (NEB), which is accompanied by metabolic disorders and by increased inflammation (Bionaz et al., 2007; Trevisi et al., 2012a), immunosuppression (Mallard et al., 1998), and oxidative stress (Sordillo et al., 2009). Proinflammatory cytokines are related to increased inflammation during NEB (Grimble, 1990; Ametaj et al., 2005) by stimulating hepatic synthesis of positive acute phase proteins (APP), such as haptoglobin and ceruloplasmin, and impairing hepatic synthesis of negative APP, such as albumin and cholesterol (Bionaz et al., 2007; LeBlanc, 2012). Cows with NEB and inflammation have higher bilirubin in plasma due to impairment of hepatic function (Bertoni et al., 2008). Paraoxonase is part of an extensive antioxidative system (Turk et al., 
2004) and is considered a negative APP (James and Deakin, 2004). In the early postpartum period, a lower plasma paraoxonase activity is positively associated with lipid metabolic disorders. Negative energy balance and high plasma free fatty acid (FFA) levels contribute to the development of fatty liver, which is in turn a contributing factor to other health concerns (e.g., metritis and retained placenta; Kaneene et al., 1997) and periparturient immunosuppression in the postpartum period (Lacetera et al., 2005; Kehrli et al., 2006).

Shortening or omitting the dry period (DP) during early lactation in dairy cows has been shown to improve energy balance (EB) (van Knegsel et al., 2014) and metabolic status (Rastani et al., 2005; Chen et al., 2015) of dairy cows in the subsequent lactation. However, earlier studies showed variable effects of dry period length (DPL) on mammary health (Pezeshki et al., 2007; Watters et al., 2008; Mayasari et al., 2016). A shortened DP (34-40 d) compared with a conventional DP (55-65 d) did not result in differences in SCC (Gulay et al., 2003; Watters et al., 2008; Shoshani et al., 2014) or clinical mastitis (CM; Enevoldsen and Sørensen, 1992; Watters et al., 2008; Shoshani et al., 2014). Other studies have shown that a shortened DP was associated with a tendency for higher SCC (Rémond et al., 1997; Annen et al., 2004) or tendency for lower SCC (Rastani et al., 2005) compared with a conventional DP. Some studies (Klusmeyer et al., 2009; Mayasari et al., 2016) concluded that omitting the DP resulted in higher SCC values compared with cows with a 56-d DP, but some studies showed no differences on SCC between cows with 0- and 56-d DP (Rastani et al., 2005; Köpf et al., 2014). Another study showed that omitting DP had a tendency for higher SCC (Rémond et al., 1997) compared with a conventional DP. To our knowledge, omitting the DP did not affect occurrence of CM (Rémond et al., 1997; Mayasari et al., 2016). The effects of shortening or omitting the DP in dairy cows on inflammatory biomarkers, liver functionality (paraoxonase and bilirubin levels), oxidative stress [reactive oxygen metabolites (ROM) and ferric-reducing antioxidant power (FRAP) levels], and creatinine as markers for mobilization of body muscle have not been reported.

We can hypothesize that when EB is improved by shortening or omitting the DP, the beneficial effects of other management strategies, such as feeding a more glucogenic ration to improve EB and metabolic health, are reduced. Earlier, we reported that cows used in the current experiment fed a glucogenic ration compared with a lipogenic ration had improved EB (van Knegsel et al., 2014) and decreased plasma BHB concentration (Chen et al., 2015), independent of DPL. In other studies, reduced FFA and BHB concentrations were associated with increased cholesterol and reduced haptoglobin levels in plasma (Bionaz et al., 2007; Trevisi et al., 2009) and reduced plasma ROM levels (Bernabucci et al., 2005; Trevisi et al., 2009). Thus, we could expect that feeding a glucogenic ration would reduce inflammation and oxidative stress of cows with different DPL.

Our hypothesis was that improving EB and metabolic status by omitting or shortening the DP would reduce the inflammatory response (i.e., higher levels of negative APP, lower levels of positive APP, and higher liver functionality) and oxidative stress (lower ROM and higher FRAP levels in plasma) during the transition period. Moreover, if omitting the DP resulted in increased SCC but no occurrence of CM, inflammatory biomarkers and oxidative stress may not be affected. The objective of this study was to evaluate effects of DPL and dietary energy source on inflammatory biomarkers and oxidative stress in plasma from dairy cows.

\section{MATERIALS AND METHODS}

\section{Animals and Experimental Design}

The Institutional Animal Care and Use Committee of Wageningen University (Wageningen, the Netherlands) approved the experimental protocol (registration number 2010026). The experimental design, DPL, and dietary contrasts were described by van Knegsel et al. (2014). In summary, 167 Holstein-Friesian dairy (60 primiparous and 107 multiparous) were selected from the Dairy Campus research herd (WUR Livestock Research, Lelystad, the Netherlands), blocked according to parity, calving date, milk yield in previous lactation, and BCS, and randomly assigned to treatments within blocks. In total, 28 blocks were used and each block consisted of 6 cows and 1 cow/treatment $(28$ blocks $\times$ 6 cows $=168$ cows; 1 cow was excluded because she received the wrong ration at drying off). Before the experiment began, all cows had SCC $<250,000$ cells/ $\mathrm{mL}$ at the last and second last monthly test-day recordings. Treatments consisted of 3 DPL $(0,30$, or $60 \mathrm{~d})$ and 2 early lactation rations (glucogenic or lipogenic) resulting in a $3 \times 2$ factorial design. Cows used in this study were clinically healthy at start of the experiment. Cows were housed in a freestall with slatted floor and cubicles, and milked twice daily (0500 and $1630 \mathrm{~h}$ ). The drying-off protocol was as follows: cows with a $30-d$ or a 60-d DP received a far-off ration $7 \mathrm{~d}$ before drying-off and were milked once daily $4 \mathrm{~d}$ before drying-off. All cows were treated with an intramammary antibiotic at drying off (Supermastidol; Virbac Animal Health, Barneveld, the Netherlands). 


\section{Rations}

Ration composition was described previously (van Knegsel et al., 2014). Prepartum, cows with 30-d and $60-d$ DP received a dry cow ration, and cows with a $0-\mathrm{d}$ DP received a lactating cow ration supporting 25 $\mathrm{kg}$ of milk yield per day. From $10 \mathrm{~d}$ before expected calving onward, cows of all treatments were fed $1 \mathrm{~kg} / \mathrm{d}$ of glucogenic or lipogenic concentrate, which was increased postcalving in steps of $0.5 \mathrm{~kg} / \mathrm{d}$ until the concentrate supply reached $8.5 \mathrm{~kg} / \mathrm{d}$. The main ingredient of the glucogenic concentrate was corn, and the main ingredients of the lipogenic concentrate were sugar beet pulp, palm kernel, and rumen-protected palm oil. A computerized feeder located in the freestall provided experimental concentrates. Cows in the parlor received $1 \mathrm{~kg} / \mathrm{d}$ of standard lactation concentrate. Forage composition did not differ among rations and was supplied ad libitum and consisted prepartum of grass silage, corn silage, wheat straw, and a protein source (rapeseed meal or soybean meal) in a ratio of 39:25:25:11 (DM basis). Postpartum, forage consisted of grass silage, corn silage, straw, and a protein source (rapeseed meal or soybean meal) in a ratio of 51:34:2:13 (DM basis). Rations were isocaloric [net energy basis: Dutch net energy evaluation (VEM) system; Van Es, 1975], and contained equal amounts of intestinal digestible protein and degraded protein balance (DVE/OEB system; Tamminga et al., 1994). Concentrate and forage were supplied separately.

\section{Milk Yield and Composition, EB, DMI, and SCC}

Milk sampling and EB calculation were described previously by van Knegsel et al. (2014). In short, milk yield was recorded daily. Milk samples for fat, protein, lactose, and SCC analysis (ISO, 2013; Qlip NV, Zutphen, the Netherlands) were collected 4 times per week (Tuesday afternoon, Wednesday morning, Wednesday afternoon, and Thursday morning). Dry matter intake was recorded weekly. Energy balance was calculated according to the VEM system (Van Es, 1975; CVB, 2005) as the difference between VEM supplied with feed and VEM required for maintenance and milk production. Animal maintenance requirements are $42.4 \mathrm{VEM} /$ $\mathrm{kg}^{0.75} \cdot \mathrm{d}$ (where $1,000 \mathrm{VEM}=6.9 \mathrm{MJ}$ of net energy). The VEM required for milk production is $442 \mathrm{VEM} / \mathrm{kg}$ of fat- and protein-corrected milk (Van Es, 1975).

\section{Blood Sampling}

Blood sampling was described previously by Chen et al. (2015). In short, blood samples from 92 cows were taken weekly from the tail vein at $3 \mathrm{~h}$ before the morn- ing feeding from wk -3 to 8 relative to calving. Blood was collected in evacuated tubes (Vacuette, Greiner BioOne, Kremsmunster, Austria) containing NaF for glucose; EDTA for insulin, FFA, BHB, and urea analysis; or lithium heparin for IGF-I, haptoglobin, ceruloplasmin, cholesterol, albumin, bilirubin, paraoxonase, ROM, FRAP, and creatinine. Samples were kept cold on ice for a maximum of $2 \mathrm{~h}$ until they were centrifuged at $3,000 \times g$ for $15 \mathrm{~min}$ at $4^{\circ} \mathrm{C}$. Plasma was decanted, aliquoted, and frozen at $-20^{\circ} \mathrm{C}$ until analysis.

\section{Laboratory Analysis}

Plasma samples for metabolite and hormones determination were analyzed at the Veterinary Physiology group of the Vetsuisse Faculty, University of Bern (Bern, Switzerland). Concentrations of glucose and urea were measured using commercial kits no. 61269 and no. 61974 from bioMérieux (Marcy l'Étoile, France), as described previously (Graber et al., 2012). Concentrations of FFA and BHB were measured enzymatically using kit no. 994-75409 from Wako Chemicals (Neuss, Germany) and kit no. RB1007 from Randox Laboratories (Ibach, Switzerland), as described previously (Graber et al., 2012). Insulin-like growth factor-1 and insulin were measured using RIA, as described previously (Vicari et al., 2008).

Inflammatory biomarkers and oxidative stress were measured at the Istituto di Zootecnica of the Università Cattolica del Sacro Cuore (Piacenza, Italy), following the procedures previously described by Bionaz et al. (2007), Calamari et al. (2016), and Jacometo et al. (2015) using a clinical auto-analyzer (ILAB 650, Instrumentation Laboratory, Lexington, MA). In short, total cholesterol (cat. no. 0018250540), albumin (cat. no. 0018250040), total bilirubin (cat. no. 0018254640), and creatinine (cat. no. 0018255540) were measured using the IL Test purchased from Instrumentation Laboratory Spa (Werfen Co., Milan, Italy). The haptoglobin was determined with the method described by Skinner et al. (1991) and Owen et al. (1960), adapted to ILAB 650 condition. The method based on peroxidase activity of methemoglobin-haptoglobin complex measured by the rate of oxidation of guaiacol (hydrogen donor) in the presence of hydrogen peroxide (oxidizing substrate). The ceruloplasmin was determined with the method described by Sunderman and Nomoto (1970), adapted to ILAB 650 conditions. The test is based on measurement of the color, which originates from the oxidation of $p$-phenylenediamine dihydrochloride induced by the ceruloplasmin. Reactive oxygen metabolites were measured using commercial kits (kit d-ROMs-test MC003; Diacron International s.r.l., Grosseto, Italy) adapted to the ILAB 650 conditions. Antioxidant potential was 
assessed as ferric-reducing antioxidant power (FRAP) using the colorimetric method of Benzie and Strain (1996). Plasma paraoxonase (PON) activity was measured by adapting the method of Ferré et al. (2002) to the ILAB 650 conditions.

\section{Statistical Analysis}

The MIXED procedure of SAS (version 9.2; SAS Institute Inc., Cary, NC; Littell et al., 1996) for repeatedmeasures analysis was used to analyze the effects of DPL and ration on inflammatory biomarkers and oxidative stress. The fixed effects were DPL $(0,30$, or 60 d), ration (glucogenic or lipogenic), parity $(2,3$, or $>3$ ), wk $(-3,-2,-1,1,2$, and 4 relative to calving), and their 2-way interactions (model 1). Cow was considered the repeated subject. All variables approximated normality of residuals by examining whether skewness and kurtosis were in a range of -2 to 2 . Four covariance structures were tested: compound symmetry, heterogeneous compound symmetry, first-order autoregressive [AR (1)], and unstructured covariance structure. Covariance structure that resulted in the smallest Akaike information criterion was used. For comparison of DPL effects, $P$-values are presented after a Tukey-Kramer adjustment. Preliminary analysis showed that effects of DPL were more pronounced in the first 2 wk after calving; therefore, data were analyzed separately for the total transition period $(-3,-2,-1,1,2$, and 4 relative to calving) and for the first 2 wk after calving. The [AR (1)] covariate structure covariance structure was the best fit and was used to account for within-cow variation. Preliminary results showed that the levels of bilirubin for all samples were relatively low compared with earlier studies (Bionaz et al., 2007; Bertoni et al., 2008; Trevisi et al., 2012a). The animal experiment was performed from 2010 until 2013, and the prolonged storage condition of the plasma samples may have affected the level of bilirubin. However, in the current study, the dynamic of bilirubin levels by week around calving followed the typical pattern of change observed in the peripartum period in earlier studies (Ametaj et al., 2005; Bionaz et al., 2007; Trevisi et al., 2012a). All plasma parameters were set with calibration curves, and data were standardized using quality control standards (internal and purchased by Instrumentation Laboratory, Lexington, MA).

Liver functionality index (LFI) was calculated according to Trevisi et al. (2012a). Albumin, cholesterol, and bilirubin data were used to calculate the LFI. The LFI calculation is carried out in 2 steps; the first step considers the values of the 3 parameters observed in wk 1 and their changes between wk 1 and 4 . In the second step, these partial indices are standardized according to average values observed in "healthy" cows. The higher the LFI, the better the adaptation of the cow to the transition period; lower LFI indicates the presence of inflammation and metabolic disorders (Trevisi et al., 2016). The LFI was calculated according to the following formula:

$$
\begin{gathered}
\text { LFI }=[(\text { albumin index }-17.71) / 1.08 \\
+(\text { cholesterol index }-2.57) / 0.43 \\
-(\text { bilirubin index }-6.08) / 2.17)] .
\end{gathered}
$$

These partial indices were categorized to 4 quartiles of LFI: low, intermediate low, intermediate-high, and high. To determine the 4 quartiles, first we ranked cows by LFI value from smallest to highest, and then we divided cows into 4 groups with equal numbers of cows in each. The high LFI value was taken to define "healthy" and "well-adapted" cows and low values were associated with a large inflammatory response and clinical health problems. Clinical health problems were defined as occurrence of metritis, fever, mastitis, or retained placenta per cow per week; these are diseases that cause an inflammatory response. Healthy cows were defined as cows not treated for disease. The frequency of clinical health problem was determined in the 4 quartiles of LFI from wk 1 to 4 postcalving. Statistical analysis for LFI was performed in the first 4 wk after calving with model 1 . Because there was only one LFI value per cow, week was excluded from the model. The AR (1) covariance structure was the best fit and was used to account for within-cow variation. Statistical analysis for milk yield, EB, SCC, plasma metabolites, and hormones were performed in the first 2 wk after calving with model 1. Cow was considered the repeated subject. The AR (1) covariate structure was determined to be the best fit and was used to account for within-cow variation. For comparison of DPL effects, $P$-values are presented after a Tukey-Kramer adjustment. The result for milk yield, EB, SCC, plasma metabolites, and hormones in the first 2 wk after calving are presented in Appendix Table A1.

To analyze whether EB, SCC, or clinical health problems (yes or no) explained the differences in inflammatory biomarkers and oxidative stress between DPL in the first 2 wk after calving, EB, SCC, and clinical health problems were included as fixed effects in the model 1. Average EB, SCC, and clinical health problems ( 1 or 0 ) were included as covariates in the model one by one. Cow was considered as the repeated subject. The AR (1) covariate structure was the best fit and was used to account for within-cow variation. For 
comparison of DPL effects, $P$-values are presented after a Tukey-Kramer adjustment. Values are presented as least squares means (LSM) with their pooled standard errors of the mean (SEM), unless otherwise stated.

\section{RESULTS}

\section{Effects of DP and Ration on Inflammatory Biomarkers in Plasma of Cows}

During the transition period from wk -3 to 4 relative to calving, cows with a 0 -d DP had higher ceruloplasmin and cholesterol levels in plasma compared with cows with a $30-\mathrm{d}$ or a $60-\mathrm{d}$ DP (Table 1 ). Cows with a 60-d DP had higher bilirubin levels compared with cows with a 30-d DP. Plasma bilirubin levels did not differ among cows with a $0-d$ DP and those with a $30-\mathrm{d}$ or 60 -d DP. The effects of DPL on inflammatory biomarkers were more pronounced in the first 2 wk after calving (Figure 1). In the first 2 wk after calving, cows with a 0-d DP had higher levels of ceruloplasmin and cholesterol and tended to have higher haptoglobin levels in plasma compared with cows with a $30-\mathrm{d}$ or a $60-\mathrm{d}$ DP (Table 2). In addition, in the first 2 wk after calving, cows with a 0 -d DP had lower plasma paraoxonase and bilirubin levels compared with cows with a 60-d DP. From wk -3 to 4 relative to calving, cows of parity $\geq 3$ had higher ceruloplasmin and lower albumin levels in plasma compared with cows of parity 2 (1.7 vs. 1.8 vs. $1.8 \pm 0.1 \mu \mathrm{moL} / \mathrm{L}$ and 37.8 vs. 36.9 vs. $36.8 \pm 0.2 \mathrm{~g} / \mathrm{L}$ for parity 2 vs. 3 vs. $>3$ for ceruloplasmin and albumin, respectively). From wk -3 to 4 relative to calving, we detected an interaction between ration and parity for cholesterol. Cows of parity $>3$ fed a glucogenic ration had higher cholesterol in plasma compared with cows fed a lipogenic ration. In contrast, cows of parity 2 fed a lipogenic ration had higher cholesterol in plasma compared with cows fed a glucogenic ration.

\section{Effects of DP and Ration on LFI in Plasma of Cows}

Cows with a 0-d DP had lower LFI compared with cows with a 30 -d or 60-d DP (Table 1). Significant interactions between $\mathrm{DP} \times$ ration and $\mathrm{DP} \times$ parity were found for LFI. We ranked cows by LFI and divided them into 4 groups with an equal number of cows, resulting in the 4 quartiles of LFI: low ( -1.70 to 0.70$)$, intermediate-low (0.86 to 2.32), intermediate-high (2.36 to 3.34), and high (3.36 to 12.00). Cows with low LFI had a higher frequency of clinical health problem (mastitis, metritis, retained placenta, and fever; 17 occurrences) compared with intermediate-low, intermediate-high, and high LFI ( 7 vs. 1 vs. 8 occurrences, respectively; $P<0.01)$.
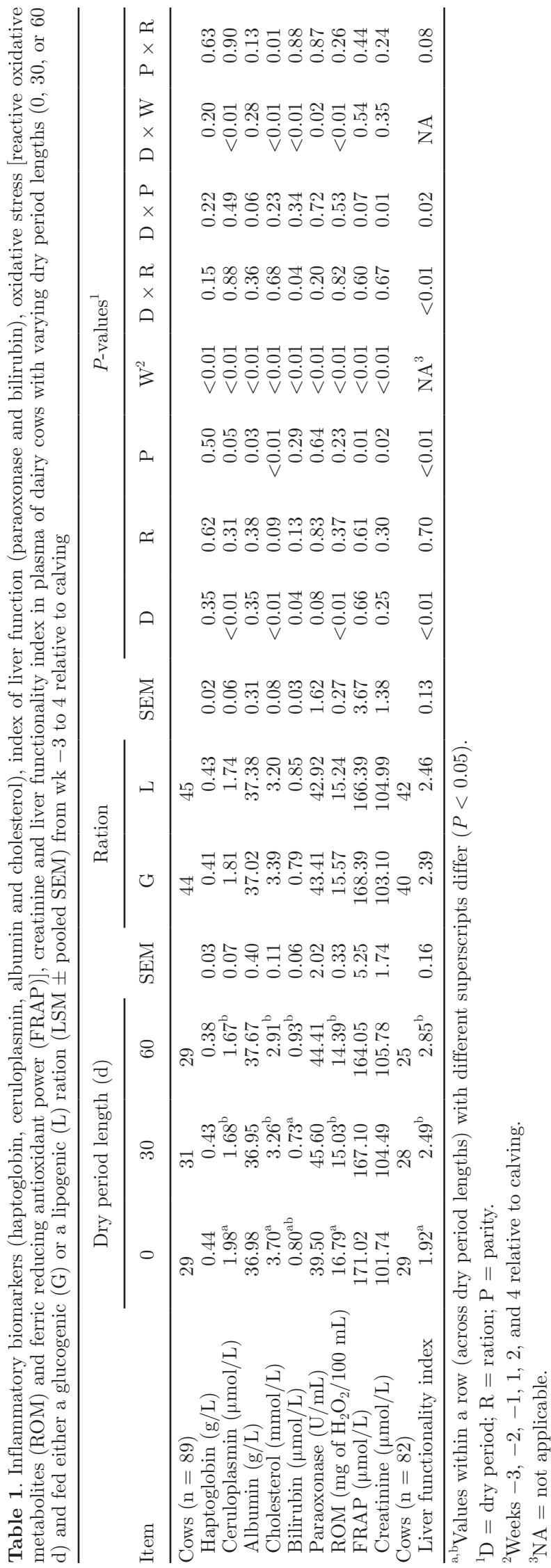

Journal of Dairy Science Vol. 100 No. 6, 2017 

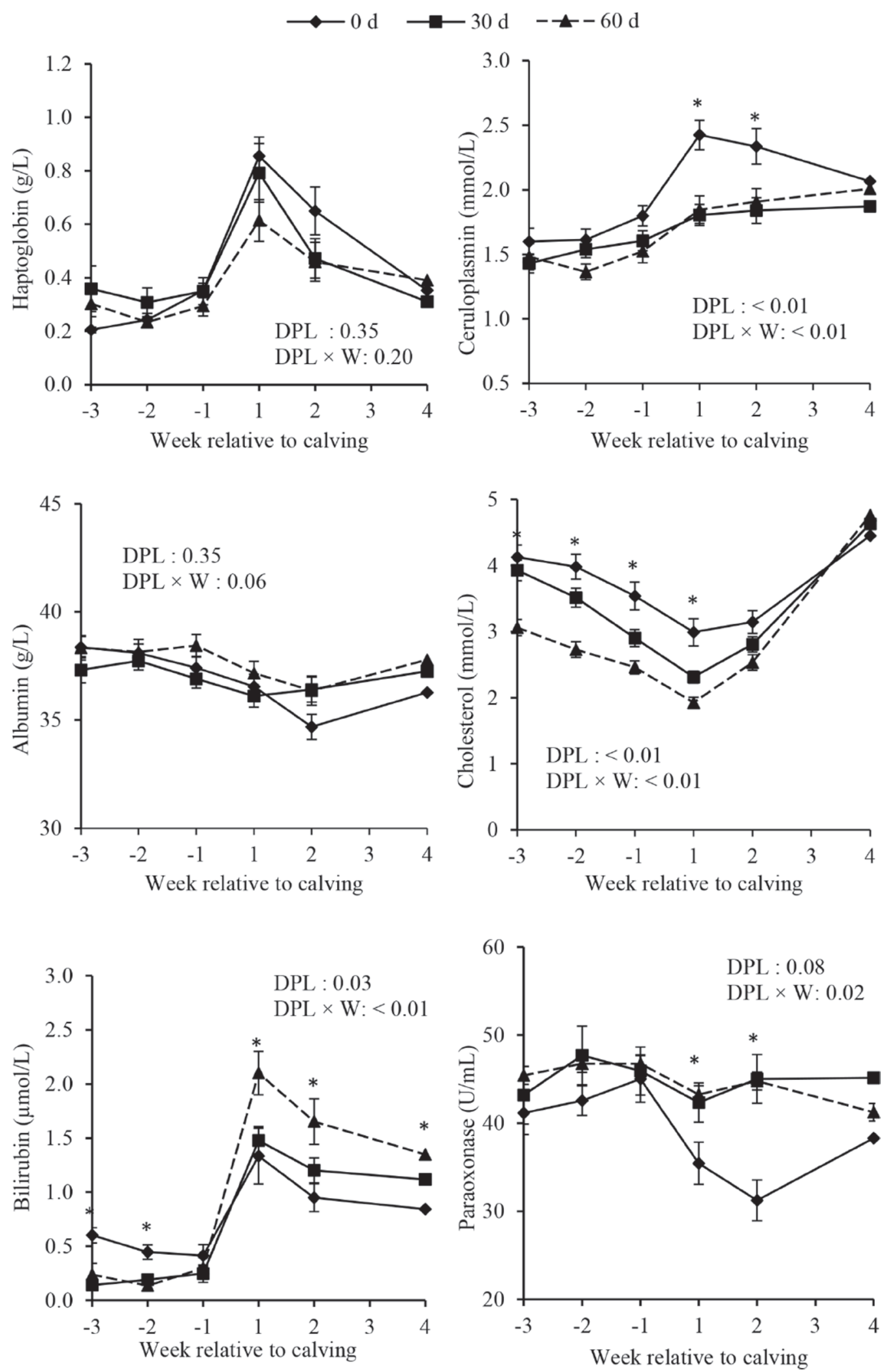

Figure 1. Inflammatory biomarkers (haptoglobin, ceruloplasmin, albumin, and cholesterol), index of liver function (paraoxonase and bilirubin), oxidative stress markers [reactive oxidative metabolites (ROM) and ferric reducing ability of plasma (FRAP)], and creatinine in plasma of dairy cows per dry period lengths $(0,30$, or $60 \mathrm{~d}$ ) per week (means $\pm \mathrm{SEM})$. $P$-values of dry period length (DPL) and interaction between DPL $\times$ week $(\mathrm{W})$ for each parameter are shown. Asterisks indicate significant $(P<0.05)$ differences between DPL within week. 


\section{Effects of DP and Ration on Oxidative Stress in Plasma of Cows}

Cows with a 0-d DP had higher levels of ROM in plasma compared with cows with a $30-\mathrm{d}$ or $60-\mathrm{d}$ DP (Table 1). The contrasts between DPL for ROM levels were more pronounced in the first 2 wk after calving. We detected no effect of DPL on FRAP levels in plasma of cows but did detect an interaction between DPL and parity for FRAP. Cows of parity $>3$ cows had lower FRAP compared with cows with parity $\leq 3$ (171.6 vs. 171.2 vs. $158.9 \pm 4.0 \mu \mathrm{mol} / \mathrm{L}$ for parity 2 vs. 3 vs. $>3$ ) in the first 2 wk after calving.

\section{Effects of DP on Creatinine, Milk Yield, DMI, EB, SCC, Plasma Metabolites, and Hormones}

There was no effect of DPL or ration on creatinine levels in plasma of cows (Tables 1 and 2). However, there was an interaction between DPL and parity for creatinine. Cows of parity $\geq 3$ had higher creatinine in plasma when they had a 0-d DP compared with cows of parity 2. Contrary, cows of parity $>3$ had lower creatinine in plasma when they had a $30-\mathrm{d}$ or $60-\mathrm{d}$ DP compared with cows of parity 2 and 3 . In the first $2 \mathrm{wk}$ after calving, cows with a 0-d DP produced less milk, had better EB, higher SCC in milk, lower FFA, higher
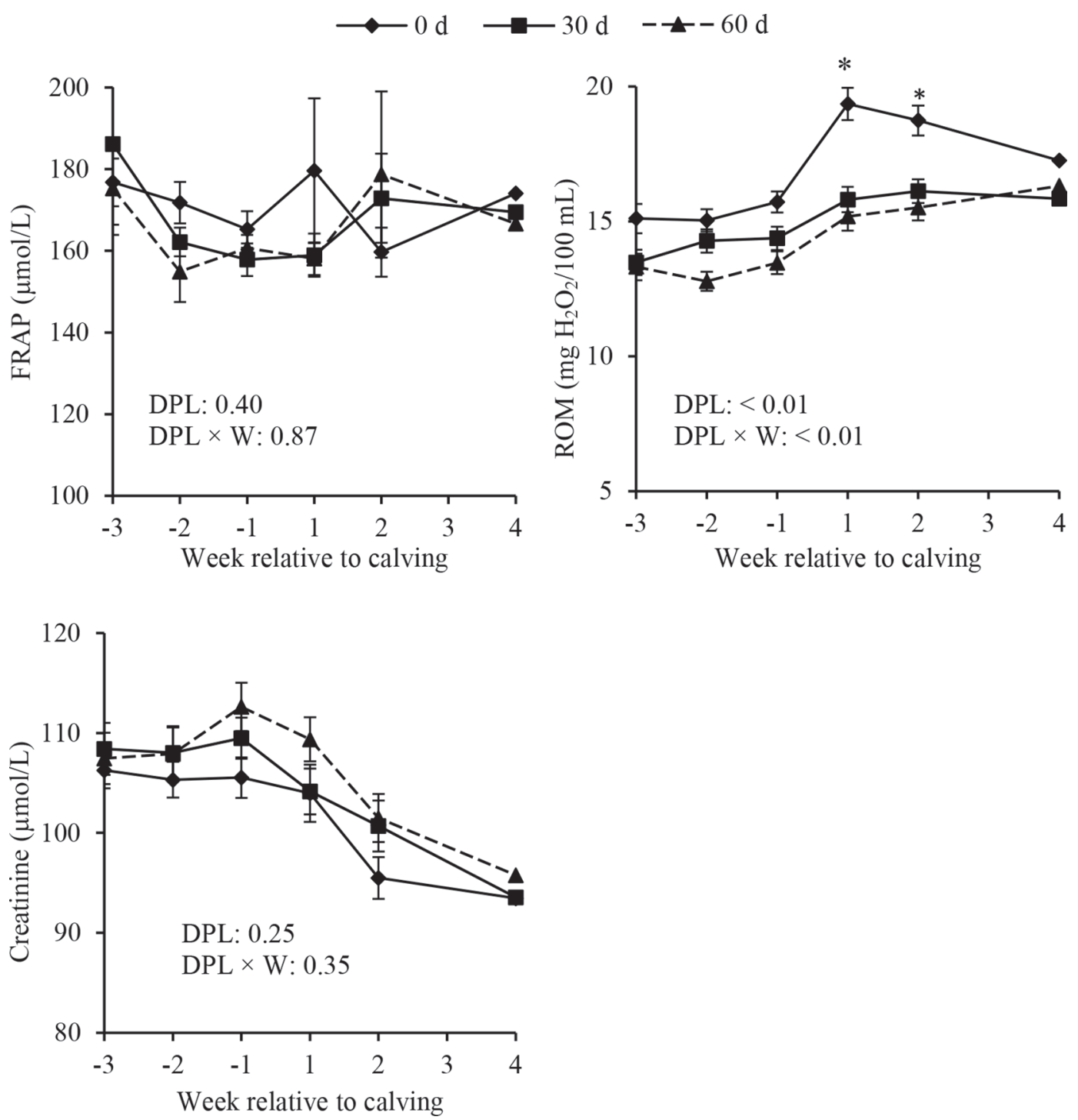

Figure 1 (Continued). Inflammatory biomarkers (haptoglobin, ceruloplasmin, albumin, and cholesterol), index of liver function (paraoxonase and bilirubin), oxidative stress markers [reactive oxidative metabolites (ROM) and ferric reducing ability of plasma (FRAP)], and creatinine in plasma of dairy cows per dry period lengths $(0,30$, or $60 \mathrm{~d})$ per week (means \pm SEM). $P$-values of dry period length (DPL) and interaction between DPL $\times$ week $(\mathrm{W})$ for each parameter are shown. Asterisks indicate significant $(P<0.05)$ differences between DPL within week. 


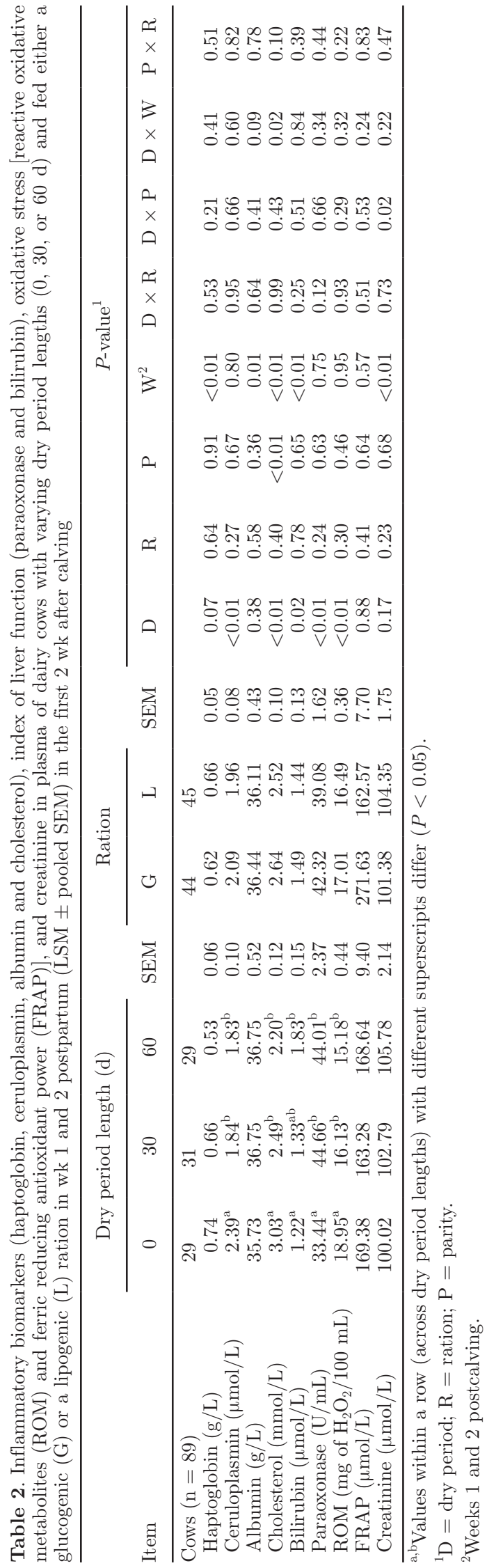

IGF-I, and higher glucose and insulin concentrations in plasma compared with cows with a $30-\mathrm{d}$ or $60-\mathrm{d}$ DP (see Appendix Table A1). In addition, DMI did not differ among DPL treatments in the first $2 \mathrm{wk}$ after calving $(P=0.95)$.

\section{Relationships of EB and SCC with Inflammatory Biomarkers and Oxidative Stress}

When EB was included as a covariate, low bilirubin levels were related to better EB in the first 2 wk after calving. Bilirubin levels between DPL were similar and not significant (Table 3).

Level of SCC was not related to levels of inflammatory biomarkers or oxidative stress except for ceruloplasmin. The relation of SCC with ceruloplasmin was dependent on parity (Table 4).

\section{Relationships of Clinical Health Problems with Inflammatory Biomarkers and Oxidative Stress}

Occurrence of clinical health problems was related to high ceruloplasmin, low albumin, low bilirubin, and high ROM, and tended to be related to high levels of haptoglobin in plasma (Table 5). The contrasts between DPL remained whether excluding or including clinical health problems in the model. In the first 2 wk after calving, occurrence of clinical health problems related to inflammation (fever, mastitis, metritis, and retained placenta) was 41,27 , and $30 \%$ for cows with $0-, 30-$, and 60-d DP, respectively (Table 6). Dry period length did not affect occurrence of clinical health problems $(P$ $=0.23)$.

\section{DISCUSSION}

\section{Effect of DPL on Inflammatory Biomarkers}

In the current study, cows with a 0-d DP compared with a 30-d or a 60-d DP had higher cholesterol and ceruloplasmin and tended to have higher haptoglobin levels in plasma, especially in the first 2 wk after calving, independent of dietary treatment. Previous studies have shown that a quicker increase in cholesterol (Kaneene et al., 1997; Trevisi et al., 2009) has been associated with a better EB and improved metabolic status in dairy cows in early lactation. In another study, reduced levels of haptoglobin and ceruloplasmin were associated with better EB (Bionaz et al., 2007). The increase of haptoglobin is related to high production of liver macrophages (known as Kupffer cells) during inflammation (Ametaj et al., 2005; Trebicka et al., 2011). The increase of ceruloplasmin has been associated with health problems in cows in early lactation (Conner et al., 1988; Chassagne et al., 1998; Sheldon et al., 2001). 


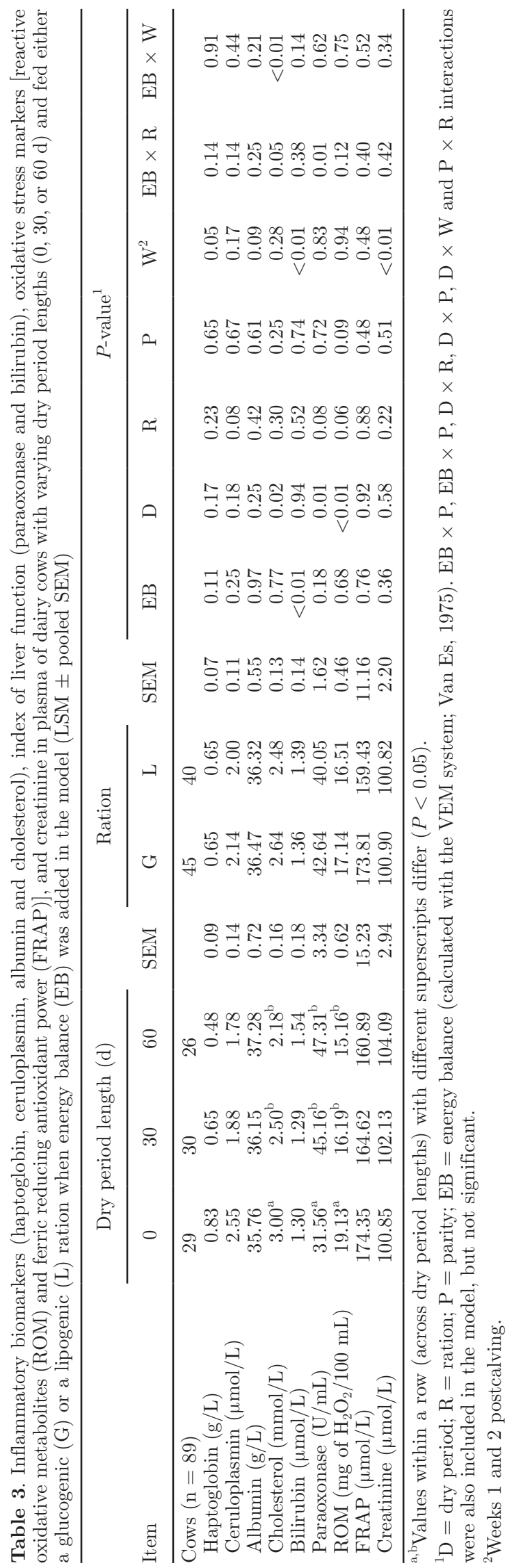
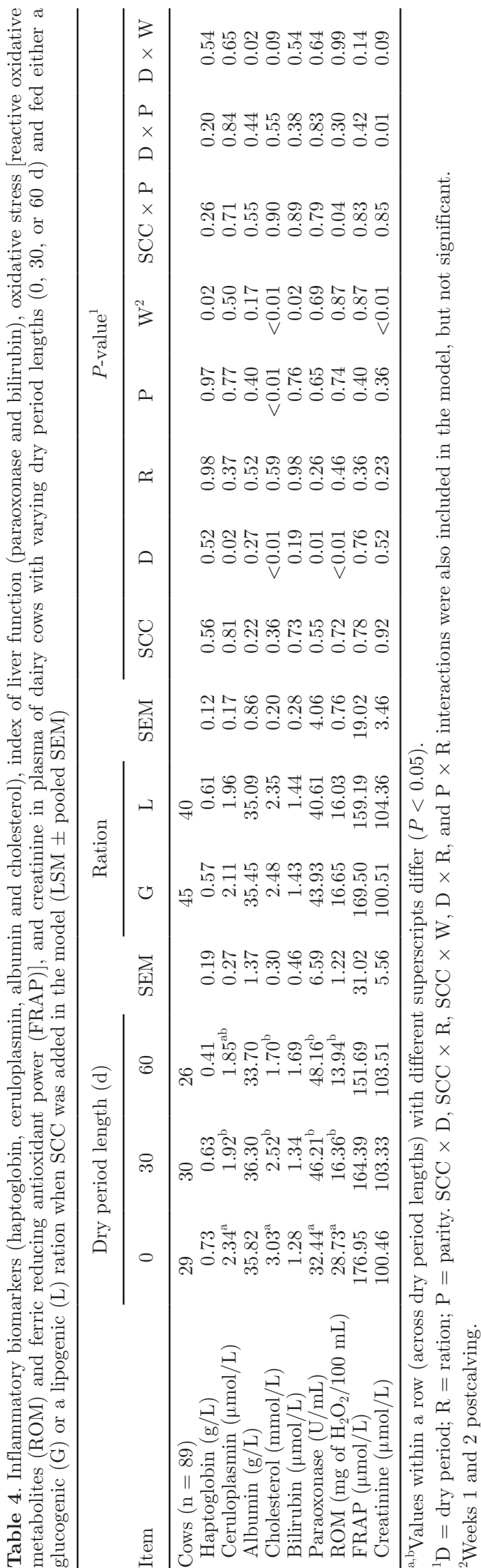


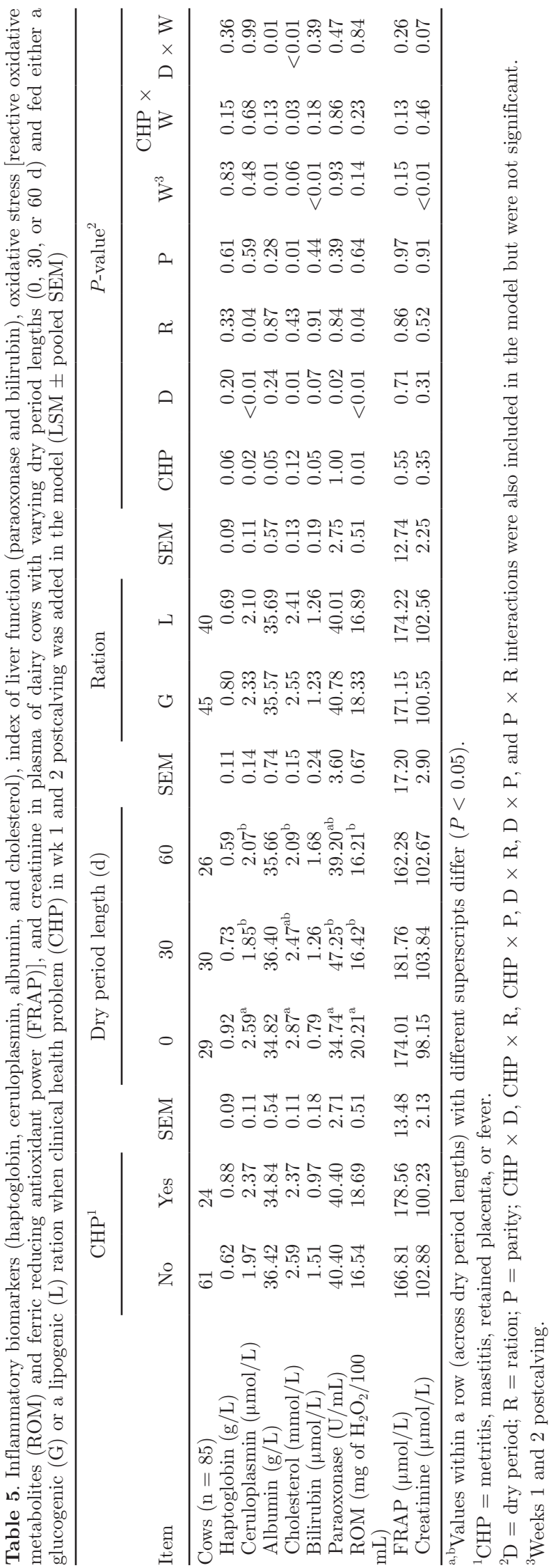

\section{Effect of DPL on Liver Functionality}

In the current study, cows with a 0-d DP had lower levels of bilirubin and paraoxonase in plasma compared with cows with a 60-d DP, especially in the first $2 \mathrm{wk}$ after calving. Bilirubin and paraoxonase are commonly used biomarkers for liver functionality status around calving (Bertoni et al., 2008; Bertoni and Trevisi, 2013). Previous studies have shown that reduced bilirubin levels indicate better clearance of secretory enzymes in the liver and are associated with a better EB and improved metabolic status in dairy cows in early lactation (Assenat et al., 2004; Bertoni et al., 2008). In the current experiment, omitting the dry period reduced milk yield, improved the EB, reduced total milk and fat- and protein-corrected milk yields, and yields of lactose, fat, and protein but did not affect DMI, compared with cows with a 60-d DP (van Knegsel et al., 2014), and not in the first weeks of lactation, which was the focus of the current study (Appendix Table A1). In the current study, DMI was negatively related to bilirubin levels ( $\mathrm{r}$ $=-0.35, P<0.01$ ), whereas milk yield was positively related to bilirubin levels $(\mathrm{r}=0.22, P<0.01)$.

Paraoxonase, a liver protein with hydrolase activity, is considered a marker of liver activity (Bionaz et al., 2007) and as a negative APP (James and Deakin, 2004). Previous studies have shown that reduced paraoxonase levels in plasma were associated with lipid metabolic disorders (Aviram and Rosenblat, 2004; Turk et al., 2004) and chronic liver damage in dairy cows (Ferré et al., 2002). In the current study, the reduced bilirubin levels in plasma after a 0-d DP might be associated with better functionality of hepatocytes related to better EB. Moreover, the decrease in paraoxonase was not associated with EB. Previously, reduced levels of paraoxonase in plasma were associated with an increased level of bilirubin in plasma (Bionaz et al., 2007; Trevisi et al., 2012b). However, in the current study, the reduced paraoxonase levels in plasma of cows with a 0-d DP was accompanied by increased haptoglobin levels $(\mathrm{r}=-0.28, P=0.03)$, which could be related to a more severe inflammatory condition (Bionaz et al., 2007; Bertoni and Trevisi, 2013) of these cows in the first $2 \mathrm{wk}$ after calving. Our study indicated that reduced paraoxonase was related to inflammation and low liver functionality of dairy cows with a 0-d DP, at least in the first 2 wk after calving.

Results of this study indicate that cows with a 0 -d DP had better clearance of waste products in the liver, as shown by a reduced level of bilirubin in plasma immediately after calving. However, in the $4 \mathrm{wk}$ after calving, the levels of bilirubin, albumin, and cholesterol in plasma of cows with a 0 -d DP resulted in lower LFI compared with cows with a $30-d$ or $60-d$ DP. The 
Table 6. Distribution of cows with different clinical health problems in wk 1 and 2 postcalving

\begin{tabular}{|c|c|c|c|c|c|c|c|}
\hline Dry period length (d) & $\mathrm{n}$ & Fever & Mastitis & Metritis & Retained placenta & Total & Total/no. $(\%)$ \\
\hline 30 & 55 & 2 & 5 & 1 & 7 & 15 & 27 \\
\hline 60 & 56 & 4 & 2 & 1 & 10 & 17 & 30 \\
\hline
\end{tabular}

LFI defines good liver functionality when the levels of bilirubin decrease and those of cholesterol and albumin increase between wk 1 and 4 in lactation (Trevisi et al., 2012a). When liver functionality, according to LFI, is poor, these levels stabilize during wk 1 to 4 in lactation. Trevisi et al. (2012a) suggested that a low LFI indicates lower liver function immediately after calving because of severe inflammation, and cows that have problems adapting to their inflammatory challenges have a low response of negative APP in the first month of lactation. In the current study, cows with a 0-d DP had high cholesterol at calving and after calving (but with a slight increase in the first month of lactation) compared with cows with a 60-d DP, which showed a marked increase from wk 1 to 4 . In addition, cows with a 0-d DP had low bilirubin at calving and a limited decrease after calving. Thus, levels of cholesterol were high but stable and levels of bilirubin were low and relatively stable for cows with a $0-d \mathrm{DP}$, whereas levels of albumin decreased after calving. This might imply that recovery of the liver is poor between wk 1 and 4 of lactation for cows with a 0-d DP, which is partly related to the high liver status at calving.

\section{Effect of DPL on Oxidative Stress}

In the first 2 wk after calving, omitting the DP increased ROM levels in plasma compared with a $60-\mathrm{d}$ DP. High ROM levels indicate conditions of high oxidative stress (Esposito et al., 2014), which is associated with severe NEB (Bernabucci et al., 2005; Pedernera et al., 2010). In the current study, the better EB due to lower milk yield in cows with a 0 -d DP was not associated with increased ROM levels in plasma. Osorio et al. (2014) suggested that oxidative stress is triggered by the imbalance between the production of ROM and the neutralizing capacity of antioxidant mechanisms (including production of FRAP) in tissues and blood. A previous study showed that increased levels of ROM in plasma were associated with reduced levels of paraoxonase as part of the extensive antioxidative system in plasma (Trevisi et al., 2012b). In the current study, omitting the DP compared with a $30-\mathrm{d}$ or $60-\mathrm{d}$ DP increased levels of ROM and reduced paraoxonase levels without affecting FRAP levels. Our results indicate that the increased of ROM levels in cows with a $0-d$
DP might be related to decreased paraoxonase levels ( $\mathrm{r}=-0.31, P=0.02)$, which indicated a more severe oxidative stress compared with cows with a $60-d$ DP.

In the current study, cows with a 0-d DP had increased levels of pro- and antiinflammatory markers, increased oxidative stress, and lower liver functionality compared with cows with 60-d DP. Inflammation and oxidative stress are associated with reduced mammary health (Pyörälä, 2003), NEB, and the occurrence of clinical health problems (Drackley, 1999; Trevisi et al., 2014). To our knowledge, only one study (Trevisi et al., 2010) has reported the relationship between inflammatory biomarkers and SCC or health status in cows with different DPL from 47 to 71 d. However, research on the relationship between SCC, EB, or clinical health problems and inflammatory biomarkers or oxidative stress in cows with different DPL $(0-d, 30-d$, or 60-d DP) is lacking. It is not clear whether the increase in proinflammatory biomarkers and oxidative stress in the current study was directly due to DPL effects or related to differences in SCC, EB, or clinical health problems.

\section{Effect of SCC on Inflammatory Biomarkers and Oxidative Stress}

In the current study, the effect of DPL on inflammatory biomarkers and oxidative stress variables could not be explained by the effect of DPL on SCC. A previous study showed that mammary gland cell differentiation and proliferation, and oxidative stress might cause inflammation during transition period (Trevisi et al., 2010). Subclinical mastitis, defined as an elevated SCC without clinical signs, was associated with increased haptoglobin levels in plasma (Safi et al., 2009). Occurrence of CM was associated with increased haptoglobin levels (Pyörälä, 2003) and bilirubin levels (Minuti et al., 2015) and decreased paraoxonase levels (Turk et al., 2012). As previously reported, in the current experiment, omitting the DP increased SCC in milk in the subsequent lactation but did not affect the occurrence of CM compared with cows with a $30-$ or a $60-d$ DP (Mayasari et al., 2016). This is in line with the present results that high SCC in cows with 0-d DP was not associated with inflammatory biomarkers and oxidative stress. 


\section{Effect of EB on Inflammatory Biomarkers and Oxidative Stress}

In the current study, low plasma bilirubin levels were associated with better EB independent of DPL. In addition, DMI was negatively related to levels of haptoglobin $(\mathrm{r}=-0.38, P<0.01)$, cholesterol $(\mathrm{r}=$ $-0.26, P<0.01)$, and bilirubin $(\mathrm{r}=-0.35, P<0.01)$. Milk yield was positively related to bilirubin levels $(\mathrm{r}=$ $0.22, P<0.01)$ independent of DPL. Previous studies showed that NEB in dairy cows is related to fatty liver, potentially affecting liver function (Ametaj et al., 2005; Bertoni et al., 2008). Bilirubin is commonly used as a biomarker for liver status around calving (Bionaz et al., 2007; Bertoni et al., 2008). Hence, it can be suggested that the effect of DPL on bilirubin levels might be associated with alterations in EB and metabolic status in the first 2 wk after calving. Moreover, liver functionality is associated with fatty acid uptake and secretion of cholesterol from triglycerides (Bell, 1995). In contrast, the lower bilirubin levels in cows with a 0-d DP immediately after calving suggest a better clearance in the liver.

\section{Effect of Health Problems on Inflammatory Biomarkers and Oxidative Stress}

In the current study, the occurrence of clinical health problems was related to high levels of ceruloplasmin, low albumin levels, low bilirubin levels, high ROM levels, and a tendency for high haptoglobin levels in plasma, independent of DPL. In addition, the levels of ceruloplasmin and ROM in plasma before calving were higher for cows with clinical health problems. This is in line with previous studies in which the occurrence of clinical health problems was associated with consequences of severe or prolonged inflammation before calving (Trevisi et al., 2011, 2012a) and oxidative stress (Trevisi et al., 2010). Our results indicate that the DPL may not directly be a causative factor for inflammation and stress. The changes in inflammatory biomarkers after calving are related to the occurrence of health problems, but many of these begin before calving and several remain subclinical.

\section{Effect of Ration and Parity on Inflammatory Biomarkers and Oxidative Stress}

Parity influenced the levels of ceruloplasmin, albumin, cholesterol, creatinine, and FRAP. Albumin levels were lower in cows of parity $>3$ compared with cows of parity 2, independent of DPL. Ceruloplasmin levels were higher in cows of parity $>3$ compared with cows of parity 2 , independent of DPL. In addition, cows of parity 2 fed a glucogenic ration had higher cholesterol levels compared with cows fed a lipogenic ration. In the current study, the differences in cholesterol levels among DPL were present from wk -3 to 1 relative to calving but did not differ after wk 1. Previously, it has been suggested that different levels of cholesterol might be affected by ration composition during the DP (Bertoni and Trevisi, 2013; Newman et al., 2016). In the current experiment, during prepartum, cows with a 0-d and 30-d DP had higher DMI and energy intake than cows with a 60-d DP (van Knegsel et al., 2014). Indeed, prepartum, cows with a 0 -d DP received a lactating ration and produced milk, whereas cows with a 30-d and 60-d DP received a dry cow ration and did not produce milk. It is likely that the differences in cholesterol levels between DPL are explained by the intake and the different rations before calving.

The changes in concentrations of APP are affected by internal and external challenges such as infection and stress (Murata et al., 2004; Ceciliani et al., 2012), which can occur in young or old animals. During the first 2 wk after calving, cows of parity $>3$ had higher creatinine and FRAP levels in plasma than cows of parity 2 when the DP was omitted. Creatinine, an indicator of body muscle mass, typically decreases around calving due to milk production (Kokkonen et al., 2005; Osorio et al., 2014). In addition, FRAP is an indicator of antioxidant status (Jacometo et al., 2015; Konvičná et al., 2015) and acts to neutralize the production of reactive intermediates caused by oxidative stress in early lactations (Esposito et al., 2014). Previous studies from Annen et al. (2004) and Santschi et al. (2011) showed a reduction in milk yield after shortening or omitting the DP for cows of parity 2, but not for cows of parity $>3$. In our study, during the first 2 wk after calving, cows of parity $>3$ showed less reduction in milk yield when the DP was omitted compared with cows of parity 2 . Therefore, it seems that the high plasma creatinine and FRAP levels in cows of parity $>3$ in the first 2 wk of lactation compared with those in cows of parity 2 indicate high mobilization of body muscle mass after calving and less stress, perhaps explained by the lesser reduction of milk yield when the DP is omitted.

\section{CONCLUSIONS}

Omitting the DP resulted in higher levels of cholesterol (negative APP), ceruloplasmin (positive APP), and ROM, lower levels of bilirubin and paraoxonase, and a lower liver functionality index, and tended to result in higher haptoglobin levels in plasma compared with cows with a 60-d DP. Omission of the DP is related to better EB and improvement of metabolic status in the early lactation due to less milk yield, which could also contribute to a reduction in inflammation and 
oxidative stress. Low bilirubin is associated with better $\mathrm{EB}$, independent of DPL. In addition, omission of the $\mathrm{DP}$ is associated with the increase of positive APP and oxidative stress, which could be explained partly by the occurrence of clinical health problems.

\section{ACKNOWLEDGMENTS}

The authors thank the Dutch Dairy Board (PZ, Zoetermeer, the Netherlands), the Product Board Animal Feed (PDV, Zoetermeer, the Netherlands), and CRV (Arnhem, the Netherlands), for financing the experiment. The authors are grateful for the scholarship of Novi Mayasari from the Directorate General of Higher Education, Ministry of National Education, Jakarta, Indonesia. The authors thank Ger de Vries Reilingh, Joop Arts, Mike Nieuwland, Gerrit Remmelink, and the staff of the Dairy Campus (Lelystad, the Netherlands) for their technical support during the experiment and the laboratory analysis.

\section{REFERENCES}

Ametaj, B. N., B. J. Bradford, G. Bobe, R. A. Nafikov, Y. Lu, J. W. Young, and D. C. Beitz. 2005. Strong relationships between mediators of the acute phase response and fatty liver in dairy cows. Can. J. Anim. Sci. 85:165-175.

Annen, E. L., R. J. Collier, M. A. McGuire, J. L. Vicini, J. M. Ballam, and M. J. Lormore. 2004. Effect of modified dry period lengths and bovine somatotropin on yield and composition of milk from dairy cows. J. Dairy Sci. 87:3746-3761.

Assenat, E., S. Gerbal-Chaloin, D. Larrey, J. Saric, J. Fabre, P. Maurel, M. Vilarem, and J. M. Pascussi. 2004. Interleukin $1 \beta$ inhibits CAR-induced expression of hepatic genes involved in drug and bilirubin clearance. Hepatology 40:951-960.

Aviram, M., and M. Rosenblat. 2004. Paraoxonases 1, 2, and 3, oxidative stress, and macrophage foam cell formation during atherosclerosis development. Free Radic. Biol. Med. 37:1304-1316.

Bell, A. W. 1995. Regulation of organic nutrient metabolism during transition from late pregnancy to early lactation. J. Anim. Sci. 73:2804-2819.

Benzie, I. F. F., and J. J. Strain. 1996. The ferric reducing ability of plasma (FRAP) as a measure of "antioxidant power": The FRAP assay. Anal. Biochem. 239:70-76.

Bernabucci, U., B. Ronchi, N. Lacetera, and A. Nardone. 2005. Influence of body condition score on relationships between metabolic status and oxidative stress in periparturient dairy cows. J. Dairy Sci. 88:2017-2026.

Bertoni, G., and E. Trevisi. 2013. Use of the liver activity index and other metabolic variables in the assessment of metabolic health in dairy herds. Vet. Clin. North Am. Food Anim. Pract. 29:413-431.

Bertoni, G., E. Trevisi, X. Han, and M. Bionaz. 2008. Effects of inflammatory conditions on liver activity in puerperium period and consequences for performance in dairy cows. J. Dairy Sci. 91:33003310 .

Bionaz, M., E. Trevisi, L. Calamari, F. Librandi, A. Ferrari, and G. Bertoni. 2007. Plasma paraoxonase, health, inflammatory conditions, and liver function in transition dairy cows. J. Dairy Sci. 90:1740-1750.

Calamari, L., A. Ferrari, A. Minuti, and E. Trevisi. 2016. Assessment of the main plasma parameters included in a metabolic profile of dairy cow based on Fourier Transform mid-infrared spectroscopy: preliminary results. BMC Vet. Res. 12:4.

Ceciliani, F., J. Ceron, P. Eckersall, and H. Sauerwein. 2012. Acute phase proteins in ruminants. J. Proteomics 75:4207-4231.
Chassagne, M., J. Barnouin, and J. P. Chacornac. 1998. Biological predictors for early clinical mastitis occurrence in Holstein cows under field conditions in France. Prev. Vet. Med. 35:29-38.

Chen, J., J. J. Gross, H. A. van Dorland, G. J. Remmelink, R. M. Bruckmaier, B. Kemp, and A. T. M. van Knegsel. 2015. Effects of dry period length and dietary energy source on metabolic status and hepatic gene expression of dairy cows in early lactation. J. Dairy Sci. 98:1033-1045.

Church, G. T., L. K. Fox, C. T. Gaskins, D. D. Hancock, and J. M. Gay. 2008. The effect of a shortened dry period on intramammary infections during the subsequent lactation. J. Dairy Sci. 91:4219-4225.

Conner, J. G., P. D. Eckersall, A. Wiseman, T. C. Aitchison, and T. A. Douglas. 1988. Bovine acute phase response following turpentine injection. Res. Vet. Sci. 44:82-88.

CVB (Centraal Veevoederbureau). 2005. Veevoedertabel. Gegevens over chemische samenstelling, verteerbaarheid en voederwaarde van voedermiddelen. CVB, Lelystad, the Netherlands.

Drackley, J. K. 1999. Biology of dairy cows during the transition period: The final frontier? J. Dairy Sci. 82:2259-2273.

Enevoldsen, C., and J. T. Sørensen. 1992. Effects of dry period length on clinical mastitis and other major clinical health disorders. J. Dairy Sci. 75:1007-1014.

Esposito, G., P. C. Irons, E. C. Webb, and A. Chapwanya. 2014. Interactions between negative energy balance, metabolic diseases, uterine health and immune response in transition dairy cows. Anim. Reprod. Sci. 144:60-71.

Ferré, N., J. Camps, E. Prats, E. Vilella, A. Paul, L. Figuera, and J. Joven. 2002. Serum paraoxonase activity: A new additional test for the improved evaluation of chronic liver damage. Clin. Chem. $48: 261-268$.

ISO (International Organization for Standardization). 2013. ISO 9622. Milk and liquid milk products. Guidelines for the application of mid-infrared spectrometry. ISO, Geneva, Switzerland.

Graber, M., S. Kohler, A. Müller, K. Burgermeister, T. Kaufmann, R. M. Bruckmaier, and H. A. van Dorland. 2012. Identification of plasma and hepatic parameters related to metabolic robustness in dairy cows. J. Anim. Physiol. Anim. Nutr. (Berl.) 96:75-84.

Grimble, R. F. 1990. Nutrition and cytokine action. Nutr. Res. Rev. $3: 193-210$

Gulay, M. S., M. J. Hayen, K. C. Bachman, T. Belloso, M. Liboni, and H. H. Head. 2003. Milk production and feed intake of Holstein cows given short (30-d) or normal (60-d) dry periods. J. Dairy Sci. $86: 2030-2038$.

Jacometo, C. B., J. S. Osorio, M. Socha, M. N. Corrêa, F. PiccioliCappelli, E. Trevisi, and J. J. Loor. 2015. Maternal consumption of organic trace minerals alters calf systemic and neutrophil mRNA and microRNA indicators of inflammation and oxidative stress. J. Dairy Sci. 98:7717-7729.

James, R. W., and S. P. Deakin. 2004. The importance of high-density lipoproteins for paraoxonase-1 secretion, stability, and activity. Free Radic. Biol. Med. 37:1986-1994.

Kaneene, J. B., R. Miller, T. H. Herdt, and J. C. Gardiner. 1997. The association of serum nonesterified fatty acids and cholesterol, management and feeding practices with peripartum disease in dairy cows. Prev. Vet. Med. 31:59-72.

Kehrli, M. E., J. D. Neill, C. Burvenich, J. P. Goff, J. D. Lippolis, T. A. Reinhardt, and B. J. Nonnecke. 2006. Energy and protein effects on the immune system. Pages 455-471 in Ruminant physiology. Digestion, metabolism and impact of nutrition on gene expression, immunology and stress. Wageningen Academic Publishers, Wageningen, the Netherlands.

Klusmeyer, T. H., A. C. Fitzgerald, A. C. Fabellar, J. M. Ballam, R. A. Cady, and J. L. Vicini. 2009. Effect of recombinant bovine somatotropin and a shortened or no dry period on the performance of lactating dairy cows. J. Dairy Sci. 92:5503-5511.

Kokkonen, T., J. Taponen, T. Anttila, L. Syrjälä-Qvist, C. Delavaud, Y. Chilliard, M. Tuori, and A. T. Tesfa. 2005. Effect of body fatness and glucogenic supplement on lipid and protein mobilization and plasma leptin in dairy cows. J. Dairy Sci. 88:1127-1141. 
Konvičná, J., M. Vargová, I. Paulíková, G. Kováč, and Z. Kostecká. 2015. Oxidative stress and antioxidant status in dairy cows during prepartal and postpartal periods. Acta Vet. Brno 84:133-140.

Köpf, M., K. Gellrich, H. Küchenhoff, H. H. D. Meyer, and H. Kliem. 2014. Effects of continuous milking during a field trial on productivity, milk protein yield and health in dairy cows. Animal $8: 1130-1138$

Lacetera, N., D. Scalia, U. Bernabucci, B. Ronchi, D. Pirazzi, and A. Nardone. 2005. Lymphocyte functions in overconditioned cows around parturition. J. Dairy Sci. 88:2010-2016.

LeBlanc, S. J. 2012. Interactions of metabolism, inflammation, and reproductive tract health in the postpartum period in dairy cattle. Reprod. Domest. Anim. 47:18-30.

Littell, R. C., G. A. Milliken, W. W. Stroup, and R. D. Wolfinger. 1996. SAS system for mixed models. SAS Institute Inc., Cary, NC.

Mallard, B. A., J. C. Dekkers, M. J. Ireland, K. E. Leslie, S. Sharif, C. L. Vankampen, L. Wagter, and B. N. Wilkie. 1998. Alteration in immune responsiveness during the peripartum period and its ramification on dairy cow and calf health. J. Dairy Sci. 81:585-595.

Mayasari, N., W. Rijks, G. de Vries Reilingh, G. J. Remmelink, B Ducro, B. Kemp, H. K. Parmentier, and A. T. M. Van Knegsel 2016. The effects of dry period length and dietary energy source on natural antibody titers and mammary health in dairy cows. Prev. Vet. Med. 127:1-9.

Minuti, A., Z. Zhou, D. E. Graugnard, S. L. Rodriguez-Zas, A. R. Palladino, F. C. Cardoso, E. Trevisi, and J. J. Loor. 2015. Acute mammary and liver transcriptome responses after an intramammary Escherichia coli lipopolysaccharide challenge in postpartal dairy cows. Physiol. Rep. 3:e12388. 10.14814/phy2.12388.

Murata, H., N. Shimada, and M. Yoshioka. 2004. Current research on acute phase proteins in veterinary diagnosis: An overview. Vet. J. 168:28-40.

Newman, A., S. Mann, D. V. Nydam, T. R. Overton, and E. BehlingKelly. 2016. Impact of dietary plane of energy during the dry period on lipoprotein parameters in the transition period in dairy cattle. J. Anim. Physiol. Anim. Nutr. 100:118-126.

Osorio, J. S., E. Trevisi, P. Ji, J. K. Drackley, D. Luchini, G. Bertoni, and J. J. Loor. 2014. Biomarkers of inflammation, metabolism, and oxidative stress in blood, liver, and milk reveal a better immunometabolic status in peripartal cows supplemented with Smartamine M or MetaSmart. J. Dairy Sci. 97:7437-7450.

Owen, J. A., F. C. Better, and J. Hoban. 1960. A simple method for the determination of serum haptoglobins. J. Clin. Pathol. 13:163164 .

Pedernera, M., P. Celi, S. C. García, H. E. Salvin, I. Barchia, and W. J. Fulkerson. 2010. Effect of diet, energy balance and milk production on oxidative stress in early-lactating dairy cows grazing pasture. Vet. J. 186:352-357.

Pezeshki, A., J. Mehrzad, G. R. Ghorbani, H. R. Rahmani, R. J. Collier, and C. Burvenich. 2007. Effects of short dry periods on performance and metabolic status in Holstein dairy cows. J. Dairy Sci. 90:5531-5541.

Pyörälä, S. 2003. Indicators of inflammation in the diagnosis of mastitis. Vet. Res. 34:565-578.

Rastani, R. R., R. R. Grummer, S. J. Bertics, A. Gümen, M. C. Wiltbank, D. G. Mashek, and M. C. Schwab. 2005. Reducing dry period length to simplify feeding transition cows: Milk production, energy balance, and metabolic profiles. J. Dairy Sci. 88:1004-1014.

Rémond, B., J. Kérouanton, and V. Brocard. 1997. Effets de la réduction de la durée de la période séche ou de son omission sur les performances des vaches laitiéras. INRA Prod. Anim. 10:301-315.

Safi, S., A. Khoshvaghti, S. R. Jafarzadeh, M. Bolourchi, and I. Nowrouzian. 2009. Acute phase proteins in the diagnosis of bovine subclinical mastitis. Vet. Clin. Pathol. 38:471-476.

Santschi, D. E., D. M. Lefebvre, R. I. Cue, C. L. Girard, and D. Pellerin. 2011. Complete-lactation milk and component yields following a short (35-d) or a conventional (60-d) dry period management strategy in commercial Holstein herds. J. Dairy Sci. 94:2302-2311.

Sheldon, I. M., D. E. Noakes, A. Rycroft, and H. Dobson. 2001. Acute phase protein responses to uterine bacterial contamination in cattle after calving. Vet. Rec. 148:172-175.
Shoshani, E., S. Rozen, and J. J. Doekes. 2014. Effect of a short dry period on milk yield and content, colostrum quality, fertility, and metabolic status of Holstein cows. J. Dairy Sci. 97:2909-2922.

Skinner, J. G., R. A. Brown, and L. Roberts. 1991. Bovine haptoglobin response in clinically defined field conditions. Vet. Rec 128:147-149.

Sordillo, L. M., G. Contreras, and S. L. Aitken. 2009. Metabolic factors affecting the inflammatory response of periparturient dairy cows. Anim. Health Res. Rev. 10:53-63.

Sunderman, F. W., and S. Nomoto. 1970. Measurement of human serum ceruloplasmin by its p-phenylenediamine oxidase activity. Clin. Chem. 16:903-910.

Tamminga, S., W. M. Van Straalen, A. P. J. Subnel, R. G. M. Meijer, A. Steg, C. J. G. Wever, and M. C. Blok. 1994. The Dutch protein evaluation system: The DVE/OEB system. Livest. Prod. Sci. 40:139-155.

Trebicka, J., A. Krag, S. Gansweid, B. Appenrodt, P. Schiedermaier, T. Sauerbruch, and U. Spengler. 2011. Endotoxin and tumor necrosis factor-receptor levels in portal and hepatic vein of patients with alcoholic liver cirrhosis receiving elective transjugular intrahepatic portosystemic shunt. Eur. J. Gastroenterol. Hepatol. 23:1218-1225

Trevisi, E., M. Amadori, I. Archetti, N. Lacetera, and G. Bertoni. 2011. Inflammatory response and acute phase proteins in the transition period of high-yielding dairy cows. Pages 355-380 in Acute Phase Proteins. 2nd ed. F. Veas, ed. InTech, Rijeka, Croatia.

Trevisi, E., M. Amadori, A. M. Bakudila, and G. Bertoni. 2009. Metabolic changes in dairy cows induced by oral, low-dose interferonalpha treatment. J. Anim. Sci. 87:3020-3029.

Trevisi, E., M. Amadori, S. Cogrossi, E. Razzuoli, and G. Bertoni 2012a. Metabolic stress and inflammatory response in high-yielding, periparturient dairy cows. Res. Vet. Sci. 93:695-704.

Trevisi, E., P. Grossi, T. Bacchetti, G. Ferretti, and G. Bertoni. 2012b. Variation factors of paraoxonase in blood and in HDL lipoproteins in dairy cow. Prog. Nutr. 14:43-49.

Trevisi, E., L. Moscati, and M. Amadori. 2016. Chapter 9: Diseasepredicting and prognostic potential of innate immune responses to noninfectious stressors: Human and animal models. Pages 209-235 in The Innate Immune Response to Noninfectious Stressors. M. Amadori, ed. Elsevier Inc., Amsterdam, the Netherlands.

Trevisi, E., A. Zecconi, G. Bertoni, and R. Piccinini. 2010. Blood and milk immune and inflammatory profiles in periparturient dairy cows showing a different liver activity index. J. Dairy Res. $77: 310-317$

Trevisi, E., A. Zecconi, S. Cogrossi, E. Razzuoli, P. Grossi, and M. Amadori. 2014. Strategies for reduced antibiotic usage in dairy cattle farms. Res. Vet. Sci. 96:229-233.

Turk, R., D. Juretic, D. Geres, N. Turk, B. Rekic, V. Simeon-Rudolf, and A. Svetina. 2004. Serum paraoxonase activity and lipid parameters in the early postpartum period of dairy cows. Res. Vet. Sci. 76:57-61.

Turk, R., C. Piras, M. Kovačić, M. Samardžija, H. Ahmed, M. De Canio, A. Urbani, Z. F. Meštrić, A. Soggiu, L. Bonizzi, and P. Roncada. 2012. Proteomics of inflammatory and oxidative stress response in cows with subclinical and clinical mastitis. J. Proteomics 75:4412-4428.

Van Es, A. J. H. 1975. Feed evaluation for dairy cows. Livest. Prod Sci. 4:95-175.

van Knegsel, A. T. M., G. J. Remmelink, S. Jorjong, V. Fievez, and B. Kemp. 2014. Effect of dry period length and dietary energy source on energy balance, milk yield, and milk composition of dairy cows. J. Dairy Sci. 97:1499-1512.

Vicari, T., J. J. G. C. van den Borne, W. J. J. Gerrits, Y. Zbinden, and J. W. Blum. 2008. Postprandial blood hormone and metabolite concentrations influenced by feeding frequency and feeding level in veal calves. Domest. Anim. Endocrinol. 34:74-88.

Watters, R. D., J. N. Guenther, A. E. Brickner, R. R. Rastani, P. M Crump, P. W. Clark, and R. R. Grummer. 2008. Effects of dry period length on milk production and health of dairy cattle. J. Dairy Sci. 91:2595-2603. 
DRY PERIOD LENGTH AND DIETARY ENERGY SOURCE

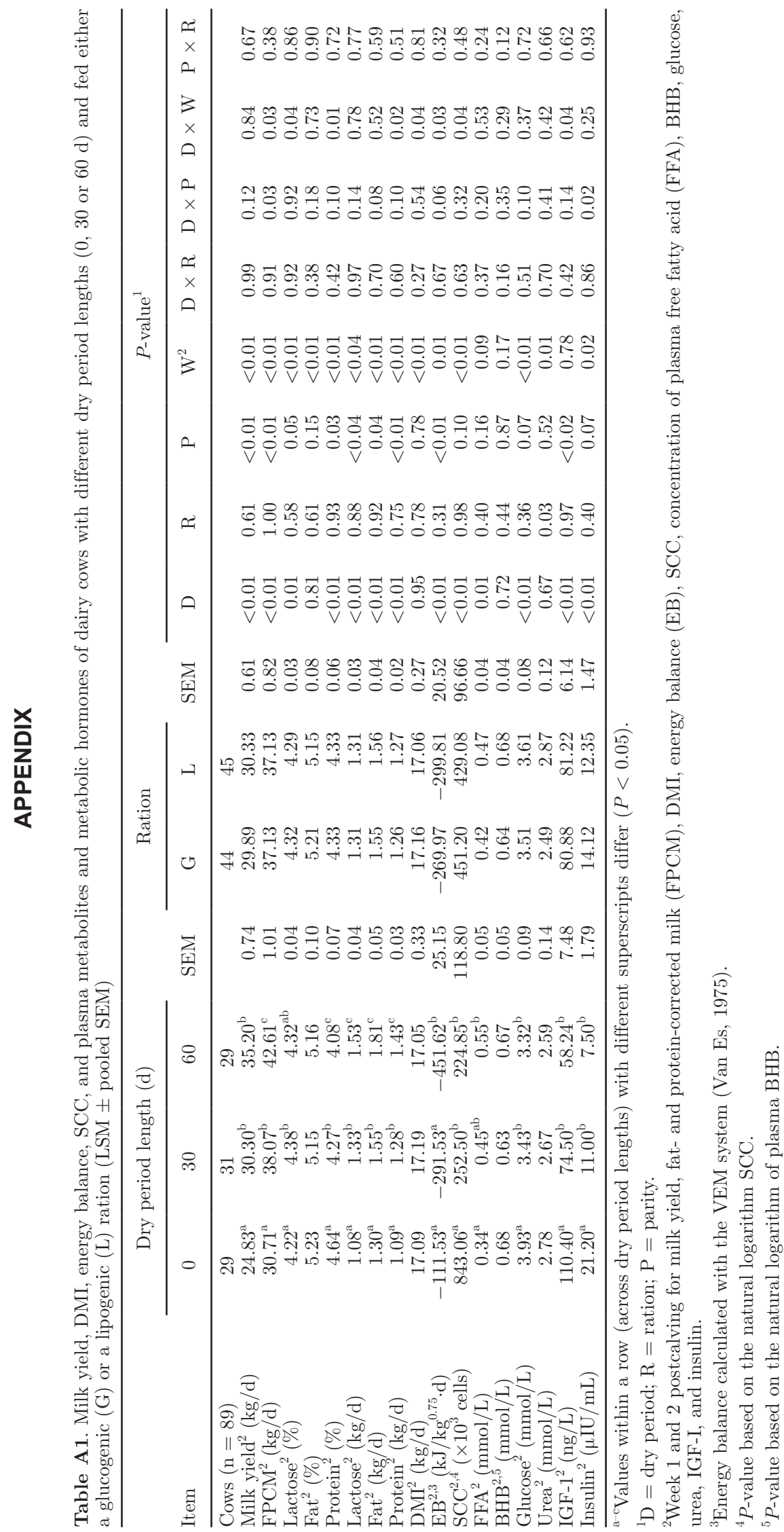

